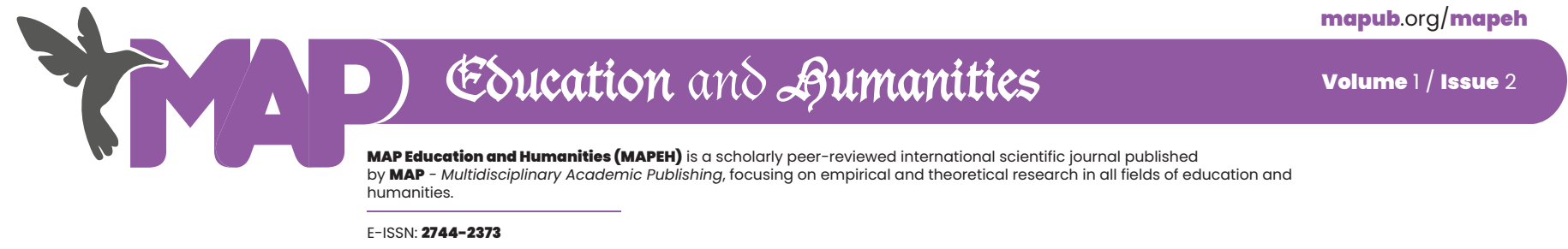

REVIEW PAPER

\title{
JaYNA DIPLOMATIJA, PROPAGANDA I UPRAVLJANJE KOMUNIKACIJAMA
}

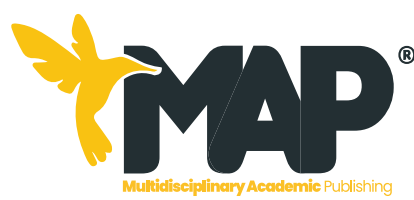

MAP EDUCATION AND HUMANITIES

Volume 1 / Issue 2

ISSN: 2744-2373/ (c) 2021 The Authors. Published by MAP - Multidisciplinary Academic Publishing.

Article Submitted: 01 October 202 Article Accepted: 15 October 202 Article Published: 05 November 202

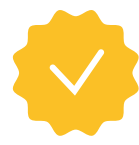
Publisher's Note: MAP stays neutral with
gard to jurisdictional claims in published maps and institutional affiliations.

\author{
Asim Šahinpašičl (i) ,Amer Džihana² (1) \\ 'International Burch University, Sarajevo, Bosnia and Herzegovina \\ ${ }^{2}$ International Burch University, Sarajevo, Bosnia and Herzegovina
}

Correspondence concerning this article should be addressed to Asim Šahinpašić, International Burch University, Sarajevo. E-mail: asim.sahinpasic@ibu.edu.ba and Amer Džihana, International Burch University, Sarajevo. E-mail: amer.dzihana@ibu.edu.ba

\section{ABSTRACT}

U ovom radu analizira se koncept javne diplomacije u odnosu na pojmove tradicionalne diplomacije i propagande, te se propituje značenje ovog pojma u kontekstu primjene koncepata meke, tvrde, i pametne moći država. Također, analizira se i upravljanja procesom komuniciranja u okviru aktivnosti javne diplomacije, kao i pitanje odnosa medija i drugih komunikacijskih kanala i javne diplomacije u novom digitalnom komunikacijskom ekosistemu. Javna diplomacija ubrzano se okreće online komunikacijskim kanalima i alatima kako bi dosegnula javnosti u stranim zemljama. U sve većoj mjeri prepoznaje se da tradicionalne metode i tehnike komuniciranja s javnostima gube na značaju i da uspješno obavljanje diplomatskih aktivnosti sve više podrazumijeva direktnu interakciju s ciljnim grupama. To otvara novo poglavlje u razvoju koncepta javne diplomacije, a pitanje interaktivnosti i dijalologa s novim ciljnim grupama dobija sve više na značaju.

Keywords: javna diplomacija, propaganda, diplomacija, upravljanje komunikacijama, online diplomacija 


\section{Escucation and diumanities \\ by MAP - Multidisciplinary Academic Publishing

\section{Uvod}

Javna diplomacija danas predstavlja glavni instrument komuniciranja $u$ diplomatskim arsenalima ambasada, stranih razvojnih agencija, međunarodnih organizacija, asocijacija i institucija koje žele da osvoje srca i umove javnosti u onim područjima, zemljama i teritorijama na kojima provode bilateralne i multilateralne diplomatske aktivnosti. Javnodiplomatske aktivnosti su komplementarne onima koje provodi tradicionalna diplomatija, ali su načini komunikacije, metode i ciljne javnosti različiti. Aktivnosti javne diplomatije se izvode simultano, ili uz podršku drugih, netradicionalnih diplomatskih aktivnosti, kao što su ekonomska, kulturna, medijska, sportska diplomacija, i sl.

Mediji i komunikacije su glavni elementi u javnodiplomatskom portfoliju. Mediji i komunikatori imaju dvostruku ulogu u javnoj diplomaciji: a) posredno, kao prenosnici informacija i b) izravno, kao aktivni kreatori javnog mnijenja.

U okviru ovoga rada predstavljena je geneza razvoja koncepta javne diplomacije, te su predstavljene razlike i sličnosti sa drugim diplomatskim i komunikacijskim aktivnostima. Ukazano je na poteškoće u razlikovanju ovog termina od propagandnih aktivnosti država, te je razmatrano korištenje javne diplomacije u primjeni različitih tipova moći kojima države raspolagaju. Na kraju su predstavljeni i ključni aspekti online/digitalne diplomacije kao novog trenda u razvoju teorije i prakse javne diplomacije.

\section{Geneza razvoja javne diplomacije}

Pojam javne diplomacije koristi se u diplomatskoj praksi te teorijama međunarodnih odnosa i diplomacije od druge polovine 20. vijeka, ali je u različitim kontekstima korišten još u 19. vijeku. Termin javna diplomacija (eng. public diplomacy) prvi put se pojavio u magazinu London Times 1856., te potom u New York Times-u 1871. i 1916. godine u kontekstu otvorene javne diplomacije. Nakon Prvog svjetskog rata, termin je koristio i predsjednik SAD-a Woodrow Wilson u govoru pred američkim Kongresom 1918. godine kada je govorio o prihvatanju principa javne diplomacije (Cull, 2006). Nakon Drugog svjetskog rata, na inauguralnoj sjednici Generalne skupštine UN-a 1946. godine, prvi predsjedavajući ovog tijela, belgijski premijer i ministar vanjskih poslova, Henri Spaak, govorio je o "novom dobu javne diplomacije". (Jelisić, 2012, p. 35-36).
Pojam javne diplomacije u savremenom značenju, prvi je upotrijebio Edmund Gullion, američki karijerni diplomata i dekan Fletcher School of Law and Diplomacy na Tufts univerzitetu, u kontekstu otvaranja Edward R. Murrow Center for Public Diplomacy na toj visokoj školi 1965. godine (Wolf, Rosen, 2004; Cull, 2009; Jelisić, 2012; PDAA, 2021). U jednoj od prvih brošura tog centra navedena je i deskriptivna definicija javne diplomacije:

Javna diplomacija ... bavi se utjecajem na stavove javnosti o formiranju i izvršenju vanjske politike. To obuhvaća dimenzije međunarodnih odnosa izvan tradicionalne diplomacije; kultiviranje vlada putem javnog mnijenja u drugim zemljama; interakciju privatnih skupina i interesa $u$ jednoj zemlji s onima u drugoj; izvještavanje o vanjskim poslovima i njihov utjecaj na politiku; komunikaciju sa onima koji se bave komunikacijom, kao i između diplomata i stranih dopisnika; te procesi inter-kulturnih komunikacija. U središtu javne diplomacije je transnacionalni protok informacija i ideja. (PDAA, 2021).

Geneza razvoja može se posmatrati kroz tri modela koja je formulirao Eytan Gilboa (2008) koji predstavljaju historijski razvoj javne diplomacije od druge polovine 20. vijeka do danas:

- Osnovni hladnoratovski model pojavio se tokom perioda hladnog rata i najviše je bio zastupljen $u$ javnodiplomatskim aktivnostima SAD-a i Sovjetskog Saveza, koji su ga koristili da prošire sfere utjecaja putem elektronskih medija, kao glavnih komunikacijskih kanala.

- Nedržavni transnacionalni model predstavlja javnodiplomatski odgovor na rast uloge i značaja nedržavnih aktera (koji ne posjeduju vlastite medije) na državnoj i međunarodnoj sceni.

- Domaći PR model bazira se na postavci da strana vlada angažuje domaću PR agenciju, kako bi osigurala veću legitimnost javnodiplomatskim kampanjama, i u isto vrijeme prikrila ko provodi te aktivnosti.

Masovni mediji su tokom historije imali veliku ulogu u razvoju javne diplomacije, a to se pokazalo tokom perioda tzv. "hladnog rata", koji je počeo nakon završetka Drugog svjetskog rata 1945. godine i trajao raspada Sovjetskog saveza i pada komunizma 1991. godine. U tom periodu "komunikacijski ratnici“, s obje strane tzv. „željezne zavjese“ između Istoka i Zapada, su koristili različite strategije 


\section{Esucation and \&umanities \\ by MAP - Multidisciplinary Academic Publishing

mas-medijske komunikacije u javnodiplomatskim aktivnostima.

Sjedinjene Američke Države (SAD) se smatraju kolijevkom javne diplomacije i zemljom koja javnodiplomatske aktivnosti koristi kao glavni komunikacijski vanjskopolitički instrument u zemljama s kojima bilateralno sarađuje, ali i na globalnom diplomatskom planu. Američko ministarstvo vanjskih poslova (eng. The United States Department of State ili U.S. State Department) koristi javnu diplomaciju kroz programe pod pokroviteljstvom vlade, kreirane s namjerom da se informira ili utiče na javno mnijenje u drugim zemljama. (U.S. Department of State, Dictionary of International Relations Terms cit. prema Wolf \& Rosen, 2004). Iz ovoga se vidi da je osnovna namjera da se putem komunikacijskog menadžmenta, usmjerenog ka ciljnim publikama u stranim zemljama, doprinosi realizaciji javnodiplomatskih ciljeva. Putem strateškog upravljanja komunikacijama informiraju se određene javnosti, a u isto vrijeme se doprinosi kreiranju javnog mnijenja tako da ima pozitivne stavove o američkim diplomatskim pristupima i otvorenim vanjskopolitičkim pitanjima.

SAD su skoro pola vijeka, kao glavni javnodiplomacijski instrument, koristile Američku informativnu agenciju (The United States Information Agency - USIA). Vlada SAD-a je razvila javnodiplomatski instrumentarij putem kojeg je promovirala svoje nacionalne interese. Tu su dominirali elektronski mediji - radio i TV - koji su emitovali programe na različitim jezicima, a neki su aktivni i danas, kao što su Glas Amerike (eng. Voice of America), Radio Slobodna Evropa (eng. Radio Free Europe) Radio i TV Liberty. Tokom Hladnog rata emitovani su i međunarodni satelitski TV programi kao što su Worldnet i Dialogue, a korišteni su i elektronski mediji prema ciljanim lokacijama kao što su radio i TV programi Marti, usmjereni prema Kubi. Na Istoku su pokrenuti međunarodni radijski programi, kao što su Radio Moskva i Kineski radio Internacional, koji su komunicirali drugu stranu hladnoratovske priče.

Nakon hladnog rata u SAD-u su pokrenuti i programi Radio Free Asia usmjereni prema Kini, te Radio Free Iraq za građane Iraka. Ove aktivnosti emitiranja RTV programa i medijske diplomacije odvijale se se u okviru USIA-a do 1999. godine, kada je ova agencija integrirana u State Department. Grupa zadužena za planiranje te integracije USIA dala je 1997. godine i novo tumačenje javne diplomacije u kojoj su razvidni elementi upravljanja komunikacijama: „Javna diplomacija nastoji pro- movirati nacionalne interese SAD-a putem razumijevanja, informiranja i utjecanja na strane publike" (PDAA, 2021). Ova definicija pokazuje značaj upravljanja komunikacijama u javnoj diplomaciji SAD-a.

Po prestanku rada USIA, u okviru State Department-a, uspostavljen je Ured za javne poslove (eng. Bureau of Public Affairs), na čijem čelu se nalazi državni podsekretar za javnu diplomaciju i javne poslove (eng. Under Secretary for Public Diplomacy and Public Affairs). Taj ured je zadužen za javnu diplomaciju i komunikaciju, ali ne i za emitiranje. Za emitiranje međunarodnih RTV programa, koje sponzorira Vlada SAD-a, zadužen je Odbor direktora za radiodifuziju (eng. Broadcasting Board of Directors), koji je nezavisan od State Department-a, a njegov rad nadzire Odbor guvernera za radiodifuziju (eng. Broadcasting Board of Governors -BBG). (Vrabec-Mojzeš, 2008).

Pored SAD-a, i druge zemlje koriste javnu diplomaciju za komuniciranje sa javnostima u stranim zemljama. Pretpostavka je da sve zemlje s razvijenom diplomatskom mrežom, u svom portfoliju koriste javnodiplomatske aktivnosti za pridobijanje pažnje javnosti u zemljama s kojima održavaju diplomatske odnose na bilateralnom i multilateralnom nivou. $U$ tom kontekstu predstavit ćemo i poziciju Europske unije (EU), koja više od pola vijeka razvija instrumente, platforme i kanale javne diplomacije.

Tako i Europska unija (EU), više od pola vijeka razvija instrumente, platforme i kanale javne diplomacije. Javna diplomacija EU razvijala se u dvije faze koje su omeđene periodom prije i poslije potpisivanja Lisabonskog ugovora (Lisabonski ugovor, 2007).

U dokumentu o naučenim lekcijama, u okviru obilježavanja 50 godina EU i pregleda rada javne diplomacije EU, prezentiran je i način na koji je EU upravljala komunikacijama s javnostima u javnodiplomatskim aktivnostima u predlisabonskoj fazi:

Javna diplomacija bavi se utjecanjem na stavove javnosti. Ona nastoji promovirati interese EU putem razumijevanja, informiranja i utjecanja. To podrazumijeva jasno objašnjavanje EU ciljeva, politika i aktivnosti i poticanje razumijevanja tih ciljeva putem dijaloga s građanima, grupama, institucijama i medijima. (European Commission, 2007, p.13).

U Priručniku za informiranje i komuniciranje EU Delegacija u trećim zemljama i međunarodnim 


\section{Esucation and \&umanities \\ by MAP - Multidisciplinary Academic Publishing

organizacijama iz 2012., predstavljen je EU pristup javnoj diplomaciji u postlisabonskom periodu, koji je u osnovi još uvijek baziran na jednosmjernoj komunikaciji:

Javna diplomacija obuhvaća niz elemenata iz zagovaranja i javnog uvjeravanja, i obično je usmjerena na medije i kreatore politika, u formi pružanja osnovnih informacija putem interneta, platformi društvenih medija, publikacija, ili eksplicitnije putem seminara i konferencija, često uključujujući informirane publike kao što su privatni sektor, akademska zajednica, organizirano civilno društvo i opšta javnost, odnosno građani. Zajednički nazivnik svih definicija "javne diplomacije" je njen krajnji cilj - poboljšanje percepcije javnosti/svijesti o (zemlji ili organizaciji kao) akteru na svjetskoj sceni. (EEAS/ DEVCO, 2012)

Javna diplomacija tokom svoje geneze prošla je kroz različite faze razvoja i ponovo se našla u fokusu javnosti početkom 21. vijeka. Brojni analitičari i teoretičari (Nye, 2004; Melissen 2005a; 2005b; Cull, 2009; Gygax, Snow, 2013) suglasni su da je novi koncept javne diplomacije nastao nakon terorističkih napada na Sjedinjene Američke Države 11. septembra 2001. godine (koji se često označava kao 9/11 period). Vlada SAD-a nakon napada 9/11 poduzima cijeli niz javnodiplomatskih kampanja $s$ ciljem informiranja javnosti u različitim zemljama svijeta, i odgovora na komunikacijske izazove koje su uputili teroristi (Gregory, 2008; Hoolbroke, 2001; Nye, 2004; Sharp, 2005). Neposredno nakon napada od 9/11, u medijima i stručnoj javnosti, fluktuirali su različiti pristupi kako efiksno odgovoriti na te izazove.

Jedna grupa eksperata, kao što su William A. Rugh, Keith Reinhard i Peter G. Peterson, ukazivali su na potrebu da se ide izvan okvira javne diplomatije i operira na nivou vojnih "strateških komunikacija". Oni su preporučivali korporativne marketinške procedure kao sredstvo da se dobije rat protiv terorizma. Bilo je i onih koji su se zalagali za integriranje javnih poslova (eng. public affairs) i javne diplomatije. Vojni establišment je propagirao korištenje instrumenata psiholoških operacija i psihološkog ratovanja (eng. psychological operations/PSYOP, psychological warfare), upravljanja percepcijom (eng. perception management) i strateškog uticaja (eng. strategic influence). Cilj je bio integrirati sve instrumente tvrde i meke moći i kreirati „totalnu diplomaciju" koja je trebala da bude svojevrstan komunikacijski hibrid. Međutim, zagovornici javne diplomatije poput Shaun Riordan i Jan Melisse- na bili su daleko oprezniji, i pristupili su rješavanju problema iz drugačije perspektive, te istakli nedostatke vojno-komunikacijskog pristupa, uključujući i probleme autoriteta i kontrole, kao i odgovornosti (Gygax, Snow, 2013: 21; Hoolbroke, 2001; Nye, 2004; Sharp, 2005).

Korištenje ratne retorike, jednosmjernih komunikacijskih kampanja, te javnodiplomatskih aktivnosti baziranih na nametanju samo jednog sistema vrijednosti (američkih), nije omogućilo da se "osvoje srca i misli" ciljnih javnosti u drugim zemljama. To je ukazalo na potrebu razvoja drugačijeg javnodiplomatskog pristupa i razvoja novog koncepta javne diplomacije.

Taj koncept karakteriše otvoren pristup i dijaloška komunikacija sa javnostima u drugima zemljama, aktivnije uključivanje aktera civilnog društva u javnodiplomatski dijalog, umrežavanje, te intenzivnije korištenje novih informacijsko-komunikacijskih tehnologija baziranih na internetu, koje omogućavaju dvosmjernu interaktivnu komunikaciju. Kao rezultat tog pristupa, sada se govori o "novoj javnoj diplomaciji”.

Jan Melissen objašnjava da "novi javnodiplomatski“ pristup naglašava to da javna diplomacija više nije ograničena na slanje poruka, promotivne kampanje, ili čak direktne vladine kontakte sa stranim javnostima $u$ inostranstvu, koje se koriste u vanjskopolitičke svrhe. Po njemu, tu se radi o izgradnji odnosa sa akterima civilnog društva u drugim zemljama i o kreiranju i održavanju mreža odnosa između nevladinih organizacija kod kuće i u inozemstvu. On smatra da će praktičari javne diplomacije sutrašnjice biti operatori u složenim transnacionalnim mrežama, te ističe da je zbog toga izgradnja povjerenja i omogućavanje prekograničnih veza civilnog društva dio njihove osnovne djelatnosti (2005b, pp. 22-23). 


\section{Esucation and doumantites \\ by MAP - Multidisciplinary Academic Publishing

Uporedni prikaz upravljanja komunikacijom stare i nove javne diplomacije

\section{Tabela 1:}

Upravljanje komunikacijom - stara i nova javna

diplomacija (Izvor. Cull, 2009)

\begin{tabular}{|c|c|c|}
\hline Dominantne karakteristike & Stara javna diplomacija & Nova javna diplomacija \\
\hline 1. Identitet međunarodnih aktera & Državni & Državni i nedržavni \\
\hline 2. Tehničko okruženje & $\begin{array}{l}\text { Kratkotalasni radio } \\
\text { Štampa, Novine, } \\
\text { Telefoni }\end{array}$ & $\begin{array}{l}\text { Satelit, Internet, } \\
\text { Vijesti u realnom vremenu, } \\
\text { Mobilni telefoni }\end{array}$ \\
\hline 3. Medijsko okruženje & $\begin{array}{l}\text { Jasna linija između } \\
\text { domaćih i međunarodnih } \\
\text { medijskih sfera }\end{array}$ & $\begin{array}{l}\text { Zamagljena granica između domaćih i } \\
\text { međunarodnih } \\
\text { medijskih sfera }\end{array}$ \\
\hline 4. Izvor pristupa & $\begin{array}{l}\text { Javna diplomacija nastala iz } \\
\text { političkog zagovaranja i } \\
\text { teorije propagande }\end{array}$ & $\begin{array}{l}\text { Javna diplomacija nastala iz } \\
\text { korporativnog brandinga i } \\
\text { teorije umrežavanja }\end{array}$ \\
\hline 5. Terminologija & $\begin{array}{l}\text { "Internacionalni imidž" } \\
\text { "Prestiž" }\end{array}$ & $\begin{array}{l}\text { "Meka moć" } \\
\text { “Brendiranje države" }\end{array}$ \\
\hline 6. Struktura uloge & $\begin{array}{l}\text { Od vrha prema dolje, akteri prema } \\
\text { ljudima u stranoj zemlji }\end{array}$ & Horizontalno, facilitirano od aktera \\
\hline 7. Priroda uloge & Ciljano slanje poruka & Izgradnja odnosa \\
\hline 8. Glavni cilj & $\begin{array}{l}\text { Upravljanje međunarodnim okružen- } \\
\text { jem }\end{array}$ & Upravljanje međunarodnim okruženjem \\
\hline
\end{tabular}

R. S. Zaharna (2010) elaborira političke i komunikacijske dinamike na međunarodnoj sceni koji se releventni za razumijevanje "nove javne diplomacije". Po njemu ove dinamike definisane su konfiguracijom 1) aktera i njihovih političkih ciljeva, 2) komunikacijskih tehnologija, i to iz perspektive komunikacije, i 3) načina na koji se ovi novi akteri organizuju i koriste te tehnologije da ostvare političke ciljeve. On smatra da ako je pomak od tradicionalne diplomatije ka javnoj diplomatiji bio u jednostavnom dodavanju novih elemenata, pomak od javne diplomacije ka novoj javnoj diplomaciji ogleda se u novoj dinamičnoj konfiguraciji tih elemenata (2010, p.83).
Tajna i javna diplomacija - tradicionalni i savremeni pristup diplomatskoj komunikaciji

Determiranje pojma javne diplomacije moguće je učiniti i upoređivanjem s "klasičnom", "tajnom" ili tradicionalnom diplomacijom, a i tu je važno strateško upravljanje komunikacijom.

Klasična diplomacija bavi se uspostavljanjem i održavanjem vanjskopolitičkih odnosa između vlada dvaju ili više zemalja. Primarno je fokusirana na zvanične odnose među vladama tih zemlja. U tom kontekstu ambasador jedne zemlje predstavlja svoju vladu u zemlji domaćina, i zadužen je za službene relacije sa zvaničnicima zemlje domaći- 


\section{Eoveation and \&umanities \\ by MAP - Multidisciplinary Academic Publishing

na. Obično se tradicionalne diplomatske aktivnosti odvijaju na sastancima "iza zatvorenih vrata", bez prisustva javnosti i medija, pa se često takav vid diplomatske komunikacije naziva i „tajna diplomacija". Javnost uglavnom dobija informacije o tim diplomatskim sastancima i aktivnostima putem saopštenja koja pripremaju uredi za odnose s javnošću ministarstava vanjskih poslova ili ambasada.

Javna diplomacija razlikuje se od tradicionalne, jer se bavi ne samo komunikacijom sa vlastima, već i sa svim relevantnim nevladinim i ne-državnim akterima (eng. non-state actors). Javnodiplomatske aktivnosti uključuju komunikaciju s pojedincima i organizacijama koje su relevantne za ambasadu, razvojnu agenciju ili međunarodnu organizaciju koja djeluje u zemlji domaćina. Takve aktivnosti uključuju predstavnike medija, civilnog društva, te organizacija i institucija iz oblasti kulture, sporta, biznisa, religijskih institucija i neformalnih grupa građana. Ti nedržavni akteri predstavljaju ključnu ciljnu javnost javnodiplomacijskih aktivnosti, jer imaju (ili mogu imati), utjecaj na politička, ekonomska, socijalna, kulturna i druga dešavanja u svojoj zemlji.

Osim ciljnih javnosti, i pozicije komunikatora u tradicionalnoj i javnoj diplomaciji su različite. $\mathrm{U}$ tradicionalnoj diplomaciji ključni komunikatori su ambasadori, članovi diplomatskog kora, ili predstavnici institucija vlasti, dok se u javnoj diplomaciji angažuju pojedinci i organizacije iz svih sfera društvenog, kulturnog, sportskog i poslovnog miljea, koji mogu prenijeti različite poruke publikama u zemlji domaćina.

Distinkciju tradicionalne i javne diplomacije moguće je sagledati i komparativnom analizom ovih pojmova. Diplomacija predstavlja vođenje državnih vanjskopolitičkih poslova posredstvom službenih odnosa s drugim državama i međunarodnim organizacijama, smatra Safet Halilović (2012), dok je za Radovana Vukadinovića (1998) diplomacija organizirana društvena djelatnost predstavljanja države u međunarodnim odnosima i realizacija državnih vanjskopolitičkih ciljeva mirnim sredstvima. Diplomatija je, Miodragu Mitiću (1999), spoljnopolitička djelatnost države u odnosu na druge subjekte međunarodnog prava i međunarodnih odnosa (države i međunarodne organizacije).

Nicholas J. Cull (2009) posmatra diplomaciju kao neratne mehanizme koje koriste međunarodni akteri za upravljanje međunarodnim okruženjem. U današnje vrijeme taj akter može biti država, multinacionalna korporacija, nevladina organizacija, međunarodna organizacija, teroristička organizacija/nedržavna paravojna organizacija ili neki drugi akteri na svjetskoj pozornici. Po Cullu, tradicionalna diplomacija predstavlja pokušaj međunarodnog aktera da upravlja međunarodnim okruženjem putem angažmana s drugim međunarodnim akterom, dok je javna diplomacija pokušaj međunarodnog aktera da upravlja međunarodnim okruženjem putem angažmana sa stranim javnostima.

Jasna Jelisić određuje pojam javne diplomacije u kontekstu aktera: „Da bi javna diplomatija bila diplomatija, u aktivnosti koje ciljaju publiku u inostranstvu mora direktno ili indirektno biti involvirana vlada, a da bi bila javna, ta publika moraju biti građani, a ne vladine strukture ili politička elita." Ona navodi da "šire definicije javne diplomatije podrazumijevaju transnacionalni impakt svih vladinih i nevladinih aktivnosti u inostranstvu koje uključuju i oblasti poput kulture i mode, sporta i interneta, a što sve u konačnici ima utjecaja na pružanje podrške vanjskoj politici“ (2012, pp. 37-38).

\section{Javna diplomacija i propaganda}

U teoriji i praksi javna diplomacija se često koristila kao sinonim za neke druge diplomatske, političke, vojne i komunikacijske aktivnosti poput propagande, psihološkog ratovanja, odnosa s javnošću, javnih poslova, međunarodnih informativnih programa, i zbog toga je potrebno objasniti razlike i diferencirati te termine.

Walter Lippmann 1953. piše o diplomatama koji u isti nivo stavljaju praksu javne diplomacije i propagande, kao i psihološkog ratovanja (Jelisić 2012, p.3). Radovan Vukadinović navodi da nekada diplomatski potezi prate propagandne aktivnosti ili se diplomatski sastanci organizuju u propagandne svrhe (1998), te smatra da je propaganda uvijek u funkciji širih vanjskopolitičkih ciljeva (2005).

Američki diplomata Richard Hoolbrook (2001), u tekstu "Get the message out" objavljenom u The Washington Postu, piše o ulozi javne diplomacije u ratu protiv terorizma: "Nazovite to javna diplomacija, ili javni poslovi, ili psihološki rat, ili ako zaista želite biti potpuno otvoreni - propaganda". Dok Geoffu Berridge (2004) smatra da je javna diplomacija strana propaganda koju provode ili poduzimaju diplomati. 


\section{Esucation and \&umanities \\ by MAP - Multidisciplinary Academic Publishing

Jedan od pionira američke javne diplomacije, John Brown (2008), postavlja pitanje da li je "javna diplomacija" samo lijep način da se kaže "propaganda"? On navodi da postoje neki zajednički elementi, ali i vrlo bitne razlike između ovih pojmova koje polarizira tako što pravi distinkciju između javne diplomacije u najboljem svjetlu i propagande u najgorem izdanju:

\section{Tabela 2:}

Uporedni prikaz javne diplomacijei propagande (izvor. Brown, 2008; tabela Šahinpašić, 2016) nom nivou diplomatskih odnosa. To se koristi kada donosioci vanjskopolitičkih odluka procijene da bi se neki diplomatski problem efikasnije riješio uz pokazivanje "meke moći", nego korištenjem alatki iz arsenala tzv. "tvrde moći" (eng. hard power) kao što su politički, vojni i ekonomski pritisci. To uključuje pokazivanje dobre volje i komunikaciju sa javnostima u drugoj zemlji, koje bi podstaknute efektima "meke moći" trebale posredno da djeluju na promjenu stavova donosioca odluka i vlasti u svojoj zemlji.

\begin{tabular}{|l|l|}
\hline Javna diplomacija (u najboljoj formi) & Propaganda (u najgoroj formi) \\
\hline $\begin{array}{l}\text { Pruža publici u inozemstvu istinita, činjenična izlaganja i obja- } \\
\text { šnjenja o nacionalnoj spoljnoj politici i načinu života u matičnoj } \\
\text { zemlji }\end{array}$ & $\begin{array}{l}\text { Publici u inozemstvu nameće svoje propagandne poruke, često } \\
\text { koristeći ponavljanje i slogane }\end{array}$ \\
\hline Podstiče razumijevanje na međunarodnom nivou & $\begin{array}{l}\text { Propaganda koristi elemente kojim se demonizira vanjski svijet, } \\
\text { uz tvrdnju da nacija koja se propagandom glorificira ne može } \\
\text { pogriješiti }\end{array}$ \\
\hline $\begin{array}{l}\text { Aktivno sluša i uključuje se u dijalog (s javnostima u zemlji } \\
\text { domaćina op.a.) }\end{array}$ & $\begin{array}{l}\text { Kompleksna pitanja predstavlja na vrlo pojednostavljen način, } \\
\text { uključujući i pitanja koja se odnose na historiju }\end{array}$ \\
\hline $\begin{array}{l}\text { Publici u inozemstvu objektivno prikazuje nacionalne uspjehe, } \\
\text { uključujući i one ostvarene na umjetničkom planu }\end{array}$ & Pogrešno predstavlja istinu, ili čak namjerno laže \\
\hline
\end{tabular}

Brown smatra da i javna diplomacija i propaganda, i u svojim najboljim i najgorim formama, mogu postići kredibilitet kod publike. Međutim, po njemu, razlika je u tome što javna diplomacija postiže dugoročni kredibilitet putem pažljive prezentacije činjenica i promišljene argumentacije na pošten način, a najgora propaganda postiže kratkoročni kredibilitet falsifikovanjem i senzacionalizmom, bez otkrivanja prave svrhe, i zbog toga je nepoštena. Brown navodi da je izuzetno teško evaluirati efikasnost javne diplomacije i propagande. On ističe da je njegova distinkcija "najbolje-najgore" bazirana na moralnim, a ne funkcionalnim argumentima. Smatra da za neke takav pristup ima malu praktičnu vrijednost, pošto po njemu, moralnost, ili poštivanje istinitosti, ima malo veze s vanjskom politikom (2008).

\section{Javna diplomacija i koncepti "tvrde", "meke" i "pametne moći"}

Javna diplomacija se posmatra kroz prizmu primjene tzv. "meke moći" (eng. soft power), koja predstavlja instrumentarij javnodiplomatskih alatki koje mogu pomoći u rješavanju otvorenih vanjskopolitičkih pitanja na bilateralnom ili multilateral-
Koncept "meke moći" je uveo Joseph G. Nye, 90-tih godina 20. vijeka kao akademski pojam kojim objašnjava sposobnost neke države da privuče i ubijedi javnosti u drugoj državi. Po njemu "tvrda moć", koja predstavlja sposobnost prisile, raste iz vojne ili ekonomske moći zemlje, dok "meka moć" proizlazi iz atraktivnost njene kulture, političkih ideala i politike koju ta zemlja vodi. "Meka moć" može pomoći državama da odgovore na izazove terorizma i kritična globalna pitanja koja zahtijevaju saradnju na multilateralnom planu (2004).

Nye (2004) razlikuje tri oblika ponašanja meke moći i to: nametanje dnevnog reda (eng. agenda setting), privlačenje i ubjeđivanje (persuazija). Postoje dva modela uticaja meke moći na ciljne javnosti: Prvi je direktni model gdje se nastoji ubijediti lidere putem predstavljanja dobrodušnosti, harizme ili vještine drugih lidera. Tu važnu ulogu imaju odnosi među elitom i mreže. Drugi model, koji se češće koristi, je dvostepeni model, u kojem se prvo utiče na javnosti u drugim zemljama, a one potom vrše uticaj na svoje lidere. U tom kontekstu, akteri poduzimaju različite aktivnosti da kreiraju 


\section{Esucation and \&umanities \\ by MAP - Multidisciplinary Academic Publishing

privlačnost i „meku moć" putem programa javne diplomatije, medijskog emitovanja, te programa razmjene i pomoći (2012).

Nye (2012) je razvio i koncept „pametne moći" (eng. "smart power"), koji uključuje različite alakte tvrde i meke moći, poput integrisanja i umrežavanja diplomatije, odbrane i razvoja. Ernest J. Wilson (2008) definira "pametnu moć" kao sposobnost aktera da kombinuju različite elemente "tvrde moći" i "meke moći" na taj način da se njihovi efekti pojačavaju međusobnim djelovanjem, što doprinosi da se namjerama aktera pristupa uspješno i efikasno. Na taj način, hibridnom kombinacijom različitih elemenata iz arsenala "tvrde moći" i "meke moći", sinhronizira se djelovanje i balansiranje elemenata moći, što omogućava više uspjeha na diplomatskom planu državi koja koristi "pametnu moć", nego onima koji koriste samo jednu vrstu moći.

To je razvidno kod primjene diplomatske taktike poznate po nazivu "mrkva i štap" (eng. carrot and stick). Izraz "mrkva i štap" predstavlja metaforičan izraz kojim se u međunarodnim diplomatskim i političkim odnosima želi opisati vrsta diplomatske ponude suprotnoj strani, koja uključuje kombinaciju nagrade i kazne za izazivanje željenog ponašanja. Na osnovu dobrog ponašanja ta strana može očekivati da će dobiti nagradu ("mrkva"), ili će biti kažnjena ("štap") ako nisu ispunjena očekivanja drugog aktera u diplomatskim odnosima. U kontekstu diplomacije, koncept nagrade ("mrkva") predstavlja manifestaciju "meke moći", a kazne ("štap") pokazivanja "tvrde moći" kroz političke, vojne i ekonomske pritiske na protivničku stranu. Sinhronizirana kombinacija i balansiranja ovih elemenata se ogleda u primjeni "pametne moći", koja uspostavlja javnodiplomatsku ravnotežu između "meke moći" i tradicionalnog diplomatskog pritiska zasnovanog na "tvrdoj moći" zemlje pregovarača.

U kontekstu primjene "pametne moći" u javnoj diplomaciji, upravljanje komunikacijama (eng. communications management) je ključno za balansiranje i komuniciranje elemenata "meke moći" i "tvrde moći" ciljnim javnostima u stranoj zemlji.

Nye (2012) predstavlja tri faze javne diplomacije koje su važne u implementaciji koncepta „'meke moći“ (vidi graf 1):

1. dnevna komunikacija, gdje je fokus na objašnjavanju odluka u domaćoj i vanjskoj politici; vrijeme se mjeri satima i danima

2. strateška komunikacija, i razvoj programa komuniciranja jednostavnih tema koji se realizuje slično kao politička ili marketinška kampanja; vrijeme se mjeri nedjeljama, mjesecima pa čak i godinama

3. razvoj dugoročnih odnosa s ključnim pojedincima putema programa kao što su stipendije, programi razmjene, obuke, seminari, konferencije i korištenje medijskih kanala; vrijeme se mjeri tokom mnogo godina pa čak i decenija.

\section{Graf 1:}

3 kruga javne diplomatije po Nye-u (2012) (adaptirao Asim Šahinpašić)

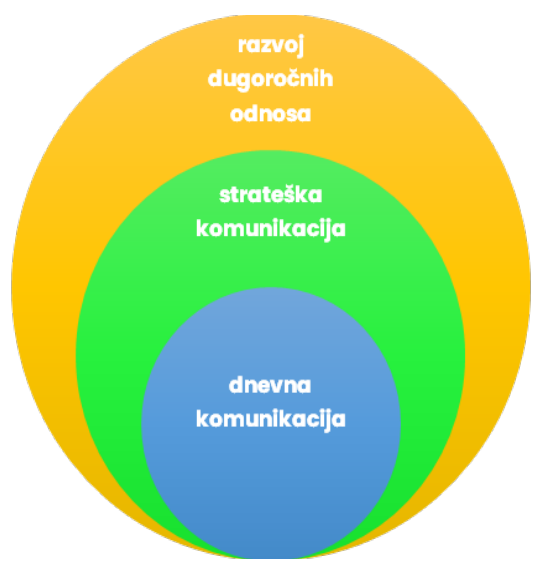

Nye (2012) ističe da svaka od ove tri faze javne diplomacije igra važnu ulogu pri pomoći vladama da stvore privlačan imidž svoje zemlje koji može popraviti njene izglede za postizanje željenog ishoda.

\section{Strateško i digitalno upravljanje komunik- acijama u javnoj diplomaciji}

Strateško upravljanje komunikacijama i odnosi s javnošću se koriste kao ključni komunikacijski instrumenti u javnoj diplomaciji. Odnosi s javnošću su u funkciji "upravljanja komunikacijom između organizacije i njenih javnosti" (Grunig, Hunt, 1984, p.7). Po Cutlipu, Centeru i Broomu (2006, p.11), "Odnosi s javnošću predstavljaju funkciju upravljanja čiji je zadatak da uspostavlja i njeguje uzajamno korisne veze između organizacije i različitih javnosti koje je okružuju, i od kojih zavisi uspjeh ili neuspjeh te organizacije." Zoran Tomić (2016, p.99) predstavlja odnose s javnošću kao "proces komuniciranja organizacije s njezinom unutarnjom i vanjskom javnošću u svrhu postizanja međusobnog razumijevanja, izgradnje društvene odgovornosti i ostvarivanja zajedničkih interesa." Na osnovu ovih 


\section{Eoveation and \&umanities \\ by MAP - Multidisciplinary Academic Publishing

tumačenja pojmova vidi se kako se strateškim upravljanjem odnosima $s$ javnošću ispunjava i javnodiplomatski zadatak povezivanja diplomatskih organizacija sa javnostima u zemlji domaćina.

Ključnu ulogu u uspostavi javnodiplomatskog komunikacijskog mosta sa javnostima igraju mediji. Zrinka Vrabec-Mojzeš (2008, p.176), navodi: "Glavni instrumenti kojima se koristi javna diplomacija jesu mediji - osobito radio i televizija, filmovi, knjige, brošure, magazini, kulturna, znanstvena i obrazovna razmjena, ali i dijalog s određenim ciljnim skupinama."

Pri provođenju kampanja i strateškom komuniciranju programa javne diplomacije koriste se i druge netradicionalne forme diplomatskih aktivnosti, za pridobijanje pažnje i povjerenja javnosti u drugim zemljama. To uključuje kulturnu diplomaciju koja provodi programi kulturne i akademske razmjene, te ekonomska, sportska, medijska i digitalna diplomacija. Javna diplomacija kreira komunikacijske mostove ka srcima i umovima javnosti u zemljama domaćina, i zato je strateško komuniciranje ključni faktor razvoja i unapređenja javnodiplomatskih aktivnosti svih zemlja koje žele osnažiti svoje diplomatske pozicije na bilateralnom i multilateralnom nivou.

U novije vrijeme, javnodiplomatske aktivnosti nalaze veliku primjenu u virtualnim komunikacijskim prostorima pri uspostavi i održavanju bilateralnih i multilateralnih odnosa u globalnoj diplomatskoj areni.

Online javna diplomacija podrazumijeva korištenje online komunikacijskih platformi na internetu i informacijsko-komunikacijskih tehnologija za realizaciju javnodiplomatskih aktivnosti. $U$ teoriji i praksi javne diplomacije, termini kao što su digitalna, ili online (javna) diplomacija, kibernetička (cyber) diplomacija, kao i e-diplomacija koriste se kao sinonimi za online javnodiplomatske aktivnosti.

U e-diplomaciji web platforme i informacijsko-komunikacijske tehnologije (IKT) pomažu u realizaciji diplomatskih ciljeva, a Hanson (2010) smatra da je u svakoj kredibilnoj javnodiplomatskoj strategiji ili kampanji potrebno uključiti i e-diplomaciju. Od aplikacije e-diplomacije koje su važne za javnu diplomaciju Hanson navodi društvene medije kao što su: Facebook, Twitter, YouTube, Digg, Flickr i Twingly, te blogove i mobilne tehnologije.
Primjena koncepta "meke" moći ima važnu ulogu i u kontekstu online javne diplomatije. Po Nye-u (2012) pradoks korištenja javne diplomatije u svrhu stvaranja "meke" moći u globalno informatičko doba jeste da decentralizacija i smanjena kontrola mogu biti ključne za stvaranje "meke" moći. Po njemu, gospodarenje ovom vrstom moći je važno, ali nije uvijek lako, naročito u kibernetičkom dobu.

Berridge (2004) navodi da odjeli zaduženi za javnu diplomaciju sve češće trebaju materijal za elektroničke i online informacije usmjeravati izravno vanjskom svijetu, posebno putem stranica ministarstava vanjskih poslova. U Digitalnoj strategiji iz 2012. Ministarstvo vanjskih poslova Ujedinjenog kraljevstva (eng. Foreign and Commonwealth office-FCO) navodi da želi vidjeti digitalne elemente ugrađene u svaki element vanjsko-političkih aktivnosti, što bi vodilo ka efikasnijem i otvorenijem radu Ministarstva vanjskih poslova (FCO-a) koje može u potpunosti iskoristiti sve prednosti umreženog svijeta (vidi FCO, 2012).

Po Fatiću (1999) kibernetika međunarodnih odnosa se direktno odražava na diplomatiju jer sugeriše da tajnovita diplomatija nema više smisla, i da je javnost diplomatije njena najveća moć. Po njemu, tri osnovne karakteristke modela kibernetike međunarodnih odnosa su: a) ubrzanje vremena (reagovanje u virtualnoj stvarnosti i u virtuelnom vremenu, paralelno sa vremenom stvarnog dešavanja), b) važnost vizuelne slike ili imidža, i c) povjerenje.

U ovom kontekstu važno je determinirati i javnu diplomaciju 2.0 (neki autori govore i o javnoj diplomaciji 3.0 kao višoj fazi). Javna diplomacija 2.0 se odnosi na javnodiplomtske aktivnosti koje se komuniciraju putem društvenih medija poput Facebooka, Twittera, YouTube-a i drugih 2.0 platformi. Glavna karakteristika web 2.0 društvenih medija je da omogućavaju interaktivnost s javnostima i participaciju korisnika u kreiranju online sadržaja, što predstavlja posebne javnodiplomatske izazove za organizacije koje žele da koriste ove online platforme za komunikaciju sa svojom publikom. I upravo ta mogućnost da publika može komunicirati sa pošiljaocima poruke je ono što predstavlja nove izazove za praktičare javne diplomacije.

Društvene mreže igraju sve važniju ulogu u javnoj diplomaciji. "Države u javnoj diplomaciji desetljećima koriste elektronske medije i internet, ali je posljednjih nekoliko godina naglo porasla popular- 


\section{Eoveation and \&umanities \\ by MAP - Multidisciplinary Academic Publishing

nost društvenih mreža preko kojih se može privući pozornost ciljane publike na mnoga pitanja koja su važna za image jedne zemlje" (Glavaš Kovačić, 2013, p.62). Tu se posebno ističe Twitter, pa je i jedan od oblika online diplomacije 2.0 nazvan - Twiplomacy.

Nove platforme za interaktivnu, dvosmjernu, komunikaciju bazirane na digitalnim online tehnologijama i društvenim medijima omogućavaju i pojedincima da se uključe u javnodiplomatske aktivnosti, čime se osnažuje uloga i pozicija građana u međunarodnim odnosima. Payne, et. al, (2011) smatraju da danas svaka osoba sa internet konekcijom može pokrenuti javnodiplomatsku inicijativu putem online platformi i društenih medija. Naravno, treba voditi računa da u takve inicijative država i ministarstva vanjskih poslova moraju biti uključeni direktno ili indirektno da bi se to moglo definirati kao aktivnost javne diplomacije.

Tradicionalne metode prezentiranja javne diplomacije gube utjecaj, smatra Nabil Ayad (2012. p.27), i sugerira diplomatama i ministarstvima vanjskih poslova da budu online, zajedno sa vladama i organizacijama, ako žele da se njihova poruka čuje, jer takav koncept omogućava direktnu interakciju i stratešku dijalošku komunikaciju s ciljnim javnostima.

\section{Zaključak}

Javna diplomacija se pojavljuje kao koncept u udžbenicima diplomacije i međunarodnih odnosa od druge polovine 20. stoljeća, a u to vrijeme se počinje koristiti i u diplomatskim praksama. Vremenom, samo značenje koncepta se mijenjalo. U hladnoratovskom periodu koncept je korišten kako bi se proširile sfere utjecaja korištenjem prvenstveno elektronskih medija. Porastom uloge nedržavnih aktera na nacionalnom i međunarodnom planu, koncept javne diplomacije je proširen da uključi i aktivnosti ovih aktera. Vremenom, koncept je postao sofisticiraniji, pa su vlade često angažirale PR agencije iz zemlje u kojoj su se provodile javnodiplomatske aktivnosti, a sve kako bi se povećao kredibilitet poruka koje se odašilju i kako bi se prikrilo ko, zapravo, provodi te aktivnosti. U novije vrijeme, nakon napada od 11. septembra 2001., pojavile su se dileme kod američkih teoretičara i praktičara na koji način odgovoriti na terorističke izazove i da li uopće nastaviti s praskom javne diplomacije, ili je uklopiti u širi okvir totalne dipomacije, koji uključuje korporativne marketinške procedure, psihološko ratovanje, upravljanje percepcijama i metode ostvarivanja strateškog uticaja. Nasuprot ovom pristupu, zagov- ornici javne diplomatije istakli su nedostatke ovog vojno-komunikacijskog pristupa, uključujući i probleme autoriteta i kontrole, odgovornosti i založili se za koncept koji karakteriše otvoren pristup i dijaloška komunikacija sa javnostima u drugima zemljama, aktivnije uključivanje aktera civilnog društva u javnodiplomatski dijalog, umrežavanje, te intenzivnije korištenje novih informacijsko-komunikacijskih tehnologija baziranih na internetu.

Određivanje pojma javne diplomacije naječešće se radi putem poređenja s tradicionalnom diplomacijom. Dvije su suštinske razlike: (1) Klasična diplomacija bavi se uspostavljanjem i održavanjem vanjskopolitičkih odnosa između vlada dvaju ili više zemalja, dok javna diplomacija nastoji uspostaviti veze s javnostima u tim zemljama. Za razliku od tradicionalne diplomacije, javna diplomacija ne komunicira samo s vlastima, već i sa svim relevantnim nevladinim i ne-državnim akterima; (2) Pozicije komunikatora u tradicionalnoj i javnoj diplomaciji su različite. U tradicionalnoj diplomaciji ključno je diplomatsko osoblje, dok se u javnoj diplomaciji angažuju pojedinci i organizacije iz svih sfera društvenog, kulturnog, sportskog i poslovnog miljea.

U pogledu odnosa javne diplomacije i propagande, nije jednostavno doći do zaključka postoji li suštinska razlika između tih pojmova. S jedne strane, određen broj autora drži da javna diplomacija je, zapravo, samo jedno lice propagandih aktivnosti, a koje provode diplomati. Nasuprot tome, drugi autori naglašavaju da postoje sličnosti, ali i bitne razlike između ova dva pojma. Razlike se ogledaju u tome da javna diplomacija nudi istinite informacije javnostima, dok se propaganda ne obazire na istinitost same poruke; zatim, da je cilj javne diplomacije podsticanje međunarodnog razumijevanja dok propaganda nastoji veličati državu i naciju iz koje potiče, istovremeno demonizirajući protivnike; i konačno, javna diplomacija nastoji potaknuti dijalog s domaćim javnostima, dok propaganda nastoji pojednostaviti stvari čineći bilo kakav dijalog izlišnim. Tako, naprimjer, EU pristup javnoj diplomaciji podrazumijeva objašnjavanje EU ciljeva, politika i aktivnosti i poticanje razumijevanja tih ciljeva putem dijaloga s građanima, grupama, institucijama i medijima. lako se ovdje ne radi o dijalogu ravnopravnih, u kojem građani drugih zemalja mogu utjecati na ciljeve, politike i aktivnosti EU-a, ipak se može primjetiti da se ovako formuliran pristup teško može ocijeniti kao propaganda.

Javna diplomacija se posmatra kroz prizmu primjene koncepata "meke", "tvrde" i "pametne" 


\section{Escucation and diumanities \\ by MAP - Multidisciplinary Academic Publishing

moći država. Posljedni od ova tri koncepta, zapravo objedinjuje prethodna dva. "Pametna" moć uključuje različite alakte tvrde i meke moći, poput integrisanja i umrežavanja diplomatije, odbrane i razvoja. U kontekstu primjene "pametne moći" u javnoj diplomaciji, upravljanje komunikacijama je ključno za balansiranje i komuniciranje elemenata "meke moći" i "tvrde moći" ciljnim javnostima u stranoj zemlji. Upravljanje komunikacijama, u tom kontekstu, uključuje: redovnu, dnevnu komunikaciju u kojoj se objašnjavaju aktuelne političke odluke; stratešku komunikaciju koja stavlja fokus na određenu temu; razvoj dugoročnih odnosa korištenjem medijskih kanala, ali i uključivanjem nemedijskih aktivnosti kao što su programi stipendiranja, razmjene, različitih obuka i slično.

U novije vrijeme, javnodiplomatske aktivnosti sve više se sele $u$ online sferu, a termini kao što su digitalna, ili online diplomacija, kibernetička diplomacija, kao i e-diplomacija koriste se kao sinonimi za online javnodiplomatske aktivnosti. U ovom kontekstu, javnodiplomatske aktivnosti su putem online alata sve više direktno usmjerene na ciljne javnosti u stranim zemljama, bez medijskih i drugih posrednika. Također, zbog prirode online komunikacijskih alata, ove aktivnosti sve više postaju i interaktivne. U ovakvim okolnostima, pojavljuju se i novi akteri u ovim aktivnostima, a to su pojedinci. Ipak, njihove aktivnosti se mogu smatrati javnodiplomatskim samo ako država, direktno ili indirektno, stoji iza ovih aktivnosti. No, sigurno je da pitanja ostvarivanja interaktivnosti, pa i sve smislenijeg dijaloga, s novim ciljnim grupama dobijaju na značaju u novom okruženju i da će koncept javne diplomacije morati odgovori na ove izazove ako želi da zadrži relevantnost.

\section{Abstract}

In this paper we analyze the concept of public diplomacy in relation to the ideas of traditional diplomacy and propaganda, and examine the meaning of this notion in the context of the application of the concepts of soft, hard, and smart power of states. Also, the management of the communication process within the activities of public diplomacy is analyzed, as well as the issue of the relationship between the media and other communication channels and public diplomacy in the new digital communication ecosystem. Public diplomacy is rapidly turning to online communication channels and tools to reach the public in foreign countries. It is increasingly recognized that traditional methods and techniques of communicating with the public are losing importance and that the successful conduct of diplomatic activities increasingly implies direct interaction with target groups. This opens a new chapter in the development of the concept of public diplomacy, and the issues of interactivity and dialogue with new target groups is becoming increasingly important.

Keywords: public diplomacy, propaganda, diplomacy, communications management, online diplomacy

\section{Reference}

Ayad, N. (2012). Rethinking Strategic Public Diplomacy: the Role of Social Media", Diplomatic Academy Proceedings, 9(1), 2012, Papers from the International Conference of the 13th CEI Dubrovnik, Diplomatic Forum "Strategic Public Diplomacy", Croatian Diplomatic Academy.

Berridge. G. R. (2004). Diplomacija, Zagreb: Politička misao.

Brown, J (2008). Public Diplomacy \& Propaganda: Their Differences, American Diplomacy, https://americandiplomacy.web.unc. edu/2008/09/public-diplomacy-propaganda-their-differences/,

Cull, N. J. (2006). Public Diplomacy Before Gullion: The Evolution of the Phrase, USC Center on Public Diplomacy.

Cull, N. J. urednik (2009). Public Diplomacy: Lessons from the Past, Los Angeles: Figueroa Press.

Cutlip, S., Center, A., Broom, G., (2003). Odnosi s javnošću, (Effective Public Relations), 8. izdanje, Zagreb: Mate.

Cutlip, S., Center, A., Broom, G., (2006). Uspešni odnosi s javnošću, (Effective Public Relations), 9. izdanje, Beograd: Službeni glasnik.

EEAS/DEVCO (2012). Information and Communication Handbook for EU Delegations in Third Countries and to International Organisations, Brussels: The Strategic Communication Division of the EEAS/DG DEVCO Communication and Transparency Unit

European Commission, Directorate-General for External Relations (2007). The EU's 50th anniversary celebrations around the world: A glance at EU public diplomacy at work, Luxembourg: Office for 


\section{Eoveation and \&umanities \\ by MAP - Multidisciplinary Academic Publishing \\ JAVNA DIPLOMATIJA, PROPAGANDA I UPRAVLJANJE KOMUNIKACIJAMA \\ Asim Šahinpašić and Amer Džihana}

Official Publications of the European Communities.

Fatić, A (1999). Novi međunarodni odnosi, Beograd: Službeni list.

FCO (2012). The FCO Digital Strategy, The Foreign and Commonwealth Office, https://www. gov.uk/government/uploads/system/uploads/attachment_data/file/39629/AB_12-11-14_Digital_ strategy.pdf

Gilboa, E. (2008). Searching for a Theory of Public Diplomacy, The ANNALS of the American Academy of Political and Social Science, Sage Publications, mart 2008. vol. 616 no. 1 55-77.

Glavaš Kovačić, L. (2013). Komunikacijski aspekti javne diplomacije, Političke analize, IV (13).

Gregory, B. (2008). Public Diplomacy and National Security: Lessons from the U.S. Experience, Small Wars Journal

Grunig, J. E., Hunt, T., (1984). Managing Public Relations, Wadsworth/Thomson Learning.

Gygax, Snow (2013). 9/11 and the Advent of Total Diplomacy: Strategic Communication as a Primary Weapon of War, Journal of 9/11 Studies, 38.

Halilović, S. (2012). Savremena diplomatija i diplomatska služba BiH, Fakultet političkih nauka Sarajevo.

Hanson, F. (2010). A Digital DFAT: Joining the 21st century, Lowy Institute, https://www. lowyinstitute.org/publications/digital-dfat-joining-21st-century.

Holbrooke, R. (2001). Get the message out, Op-Eds for The Washington Post, Oct. 28, 2001, http://www.washingtonpost.com/wp-dyn/content/article/2010/12/13/AR2010121305410.html.

Jelisić, J. (2012). Javna diplomatija: ka evropskom glasu u globalnom dijalogu, Synopsis.

Lisabonski ugovor (2007). Treaty of Lisbon amending the Treaty on European Union and the Treaty establishing the European Community, signed at Lisbon, 13 December 2007", Official Journal of the European Union, C 306/01 Volume 50, 17 December 2007.

Melissen, J. urednik (2005a). The New Public Diplomacy: Soft Power in International Relations, (Studies in Diplomacy and International Relations),
Palgrave Macmillan.

Melissen, J. (2005b). The New Public Diplomacy: Between Theory and Practice, u Melissen, J. urednik: The New Public Diplomacy. Soft Power in International Relations, (Studies in Diplomacy and International Relations), New York: Palgrave Macmillan.

Nye J. S. Jr., (2004). Soft Power. The Means To Success In World Politics, New York: Public Affairs.

Nye, J. S. (2010). "New public diplomacy", https://www.project-syndicate.org/commentary/ the-new-public-diplomacy-2010-02.

Nye J. S. (2012). Budućnost moći, Beograd: Arhipelag.

PDAA (2021). About U.S. Public Diplomacy, PDAA - Public Diplomacy Association of America, https://pdaa.publicdiplomacy.org/?page_id=6.

Payne, G., Sevin, E., Bruya, S., (2011). Grassroots 2.0: Public Diplomacy in the Digital Age, Comunicação Pública [Online], 6(10), http://cp.revues. org/422; DOI: $10.4000 / c p .422,45-70$.

Mitić, M. (1999). Diplomatija, Beograd: Zavod za udžbenike i nastavna sredstva.

Sharp, P. (2005). Revolutionary States, Outlaw Regimes and the Techniques of Public Diplomacy, u Melissen, J. urednik, The New Public Diplomacy. Soft Power in International Relations, (Studies in Diplomacy and International Relations), New York: Palgrave Macmillan.

Šahinpašić, A. (2016). EU javna diplomacija: Teorijski i empirijski aspekti online javne diplomacije europske unije u Bosni i Hercegovini, Crnoj Gori, Hrvatskoj i Srbiji, nepublicirana magistarska teza, Fakultet političkih nauka Univerziteta u Sarajevu.

Titolo, A. (2012). New Technologies and Social Media, u Diplomatic Academy Proceedings, 9(1), Papers from the International Conference of the 13th CEI Dubrovnik, Diplomatic Forum "Strategic Public Diplomacy", Zagreb: Croatian Diplomatic Academy.

Tomić, Z., (2016). Odnosi s javnošću- Teorija i praksa, 2. dopunjeno i izmijenjeno izdanje, synopsis. 
US Embassy (2021). Zvanična web stranica Ambasade SAD u BiH, https://ba.usembassy.gov/ education-culture/educational-exchanges/

Vrabec-Mojzeš, Z. (2008). “Javna diplomacija i mediji", MediAnali: međunarodni znanstveni časopis za pitanja medija, novinarstva, masovnog komuniciranja i odnosa s javnostima, 2 (4), 175-198.

Vukadinović, R. (1998). Međunarodni politički odnosi, Zagreb: Barbat.

Vukadinović, R. (2005). Teorije vanjske politike, Zagreb: Politička kultura.

Wilson, E. J. (2008). Hard Power, Soft Power, Smart Power, The Annals of the American Academy of Political and Social Science, 616, 110-24. http:// www.jstor.org/stable/25097997,

Wolf, C., Rosen, B. (2004). „Public Diplomacy-How to Think About and Improve It", Santa Monica: RAND Corporation.

Zaharna, R. S. (2010). Battles to Bridges - U.S. Strategic Communication and Public Diplomacy after 9/11, New York: Palgrave Macmillan. 